\title{
The Suitability Rule and Economic Theory
}

\author{
Stephen B. Cohen†
}

The published rules of both the National Association of Securities Dealers (NASD) and the Securities and Exchange Commission (SEC) provide that a broker or dealer ${ }^{1}$ in the securities market may recommend the purchase of a security only when there is a reasonable basis for believing that the security is "suitable" for the customer. The NASD rule, which applies only to its members, provides:

In recommending to a customer the purchase, sale or exchange of any security, a member shall have reasonable grounds for believing that the recommendation is suitable for such customer upon the basis of the facts, if any, disclosed by such customer as to his other security holdings and as to his financial situation and needs. ${ }^{2}$

The SEC rule applies to brokers and dealers who are not members of the NASD. It states that

[e]very nonmember broker or dealer and every associated person who recommends to a customer the purchase, sale or exchange of any security shall have reasonable grounds to believe that the recommendation is not unsuitable for the customer on the basis of information furnished by such customer after reasonable inquiry concerning the customer's investment objectives, financial situation and needs, and any other information known by such broker or dealer or associated person. ${ }^{3}$

Broker-dealers who violate the "suitability requirement" are subject to disciplinary action by the NASD or SEG." Moreover, in several in. stances a disappointed investor has sued his broker for the loss caused

- Acknowledgment is due to Professor Marvin Chirclstein of Yale Law School who suggested this topic to the author.

$t_{1}$ Assistant Professor of Law, Rutgers Law School, Newark. A.B. 1967, Amherst; LL.13. 1971, Yale.

1. Throughout this article, the term "broker" will be used to refer to both brokers and dealers.

2. CGH NASD Manual I 2152, art. III (Rules of Fair Practice), § 2.

3. 17 C.F.R. \$ 240.15bl0-3 (1971).

4. Under the Securities Exchange Act of 1934, the NASD has authority to fine or suspend from the securities business members who violate NASD rulcs, but its decisions are subject to review by the SEC. The SEC can take action directly against NASD nont. members who violate the SEC suitability rule. 
by an unsuitable recommendation, ${ }^{5}$ and at least one court has awarded damages in such an action. ${ }^{6}$

The rules, as drafted, raise several important questions. What, for example, is the extent of the broker's responsibility to obtain facts about his customer? Is that duty lighter under the NASD rule than under the SEC rule?" Does a broker "recommend" a security when, acting as an order clerk, he merely executes a buy or sell order:33 Also unclear are the remedies under the rule. May a customer maintain a private right of action for violation of the suitability requirement, or is it merely a rule of ethical conduct which does not give rise to implied civil liability? Although these issues have been extensively

5. Hecht v. Harris, Upham \& Co., 430 F.2d 1202 (9th Cir. 1970); Alercury Investment Co. v. A. G. Edwards and Sons, 295 F. Supp. 1100 (S.D. Texas 1969); Tromey v. Mlitchum, 262 Cal. App. 2d 690, 69 Cal. Rptr. 222 (1968).

There has been almost no discussion of the proper measure of damages in a suit for the loss caused by the recommendation of an unsuitably high risk. One possible coursc would be to adopt a recission standard under which the customer would receive his purchase price plus interest since the date of the purchase. An alternative standard vould be to award compensation in terms of the actual damage caused, thereby placing the customer in the same economic position he would have been in had a suitable recommendation been made. The recission standard provides the investor with the equiralent of a risk-free investment at a fixed rate of interest calculated from the date of purchase, with no possibility of a larger or smaller return. This is to be contrasted with the situstion under the actual damages standard which requires the investor to assume the possibility of either a larger or smaller return, depending upon the way a suitable recommendation vould have behaved in fact. If the suitable recommendation would have produced some return greater than the fixed interest arvarded under the recission standard, then the investor loses under the recission standard. If the suitable recommendation would have produced the same return, then both standards produce identical results. If the suitable security would have produced a lower return, then the investor gains under the recission standard at the expense of the defendant-broker. The recission standard is thus unfair in two respects. It makes the investor an insurer of the broker against the possibility that the security would have produced a larger return, and it makes the broker an insurer of the customer against the possibility that the suitable sccurity would have produoed a lower return.

In order to preserve the risk of both loss and gain for the investor, the actual damages standard would measure the amount of compensation by comparing the performance of the unsuitable security that was actually recommended with the performance of the security that would have been purchased had the customer received a suitable recommendation. In practice, there would usually be hundreds of securities which it would have been suitable to recommend in any given instance. Moreover, during the relevant time period these securities will have produced a wide range of different returns. Therefore, in measturing the actual damages, one would have to take the average return of a fair sample of securities that would have been suitable, and compare this to the return actually produced by the unsuitable recommendation.

6. Twomey v. Mitchum, 262 Cal. App. 2d 690, 69 Cal. Rptr. 222 (1968).

7. This possible difference arises from the fact that the SEC rule expressly imposes a positive duty on brokers to obtain facts about their customers, while the NASD rule requires merely that a recommendation be suitable on the basis of the facts, if any, disclosed by the customer about himself. It is unclear whether the NASD rule means that the broker has no duty to make any inquiry himself or whether it simply means that the rule does not apply when the customer refuses, after inquiry, to disclose facts about his financial situation and needs. See Mundheim, Professional Responsibilitics of BroherDealers: The Suitability Doctrine, 1965 DukE L.J. 445, 456-57, 473-74.

8. Id. at 450 . 
discussed, ${ }^{9}$ there has been almost no consideration of what is probably the most important question of all: What is the meaning of the word "suitable," and what are the appropriate standards for judging the suitability of a particular security with respect to a given customer?

The federal courts have considered several cases arising under the suitability rule, but to this date have decided them on other grounds, without determining whether the purchases recommended were suitable or not. ${ }^{10}$ Neither the NASD nor the SEC has made fully explicit what is meant by a "suitable" recommendation."1 Decisions of the NASD are confidential, and the SEC has merely held that certain fact situations involve an unsuitable recommendation, without attempting to formulate a general rule.12 The SEC has found violations of the suitability requirement when a broker-dealer failed to make any inquiry at all concerning a customer's financial situation, ${ }^{13}$ when there has been "churning" or excessive trading in a discretionary account, ${ }^{14}$ and when a speculative security has been recommended to a customer with limited financial means. ${ }^{15}$ Commentators have assumed that suitability turns on whether the purchase of a security involves the assumption of a risk that is suitable for the customer's financial needs and objectives. ${ }^{16}$ But they have failed, for the most part, ${ }^{17}$ to suggest specific criteria for judging the risk suitability of particular recommendations.

9. Fishman, Broker-Dealer Obligations to Customers-The NASD Suitability Rule, bI MINN. L. REv. 233 (1966); MacLean, Brokers Liability for Violation of Exchange and NASD Rules, 47 DENVER L. REv. 63 (1970); Mundheim, supra note 7; Redilicr, Civill Liability of Broker-Dealers and SEC and NASD Suilability Rules, 22 ALA. L. REv. 15 (1970); Comment, Current Problems in Securities Regulation, 63 Mich. L. Rev. 680 (1961).

10. See note 5 supra.

11. A statement of "General Policy," accompanying the suitability rule in the NASD Manual, declares that NASD members are expected to deal fairly and to abstain from fraudulent and deceptive practices. There follow several examples of forbidden conduct which include: the indiscriminate recommendation of speculative, low-priced securlitics; churning or excessive trading; short-term trading in mutual funds; and recommending purchases beyond a customer's capability to pay for them. NASD Manual, supra note 2 . Beyond that, there is no attempt to provide substantive content to the word "suitability."

12. The SEC has not yet considered any case involving its own version of the suitability requirement. All of its decisions in this area are in review of proceedings initiated by the NASD for violations of the NASD suitability rule.

13. See, e.g., C. Gilman Johnston, SEC Release No. 34.7390 (August 14, 1961); Best Securities, Inc., 39 S.E.C. 931 (1960); Gerald M. Greenberg, 30 S.E.C. 133 (1960); Boren and Co., SEC Release No. $34-6367$ (September 19, 1960).

14. First Securities Corp., SEC Release No. 34-6497 (March 20, 1961); Thomas Arthur Stewart, 20 S.E.C. 196 (1945).

15. Richard N. Cea, SEG Release No. $34-8662$ (August 6, 1969); Philips and Co., 87 SEG 66 (1956).

16. Mundheim, supra note 7, at 448; Fishman, supra note 9, at 248; Rediker, supra note 9 , at 25 .

17. Mundheim, supra note 7 , at 452 , indicates that suitability should take account of the effect of a security on the investor's entire portfolio. 
Economists, however, have developed a model of portfolio selection which suggests definite standards, at least in theory, for judging the advisability or suitability of any investment. ${ }^{18}$ This article will examine the portfolio concept of risk suitability and suggest a way of using that theoretical model to provide additional substantive content to the legal standard.

\section{The Economic Theory and its Limitations}

\section{A. Portfolio Theory}

\section{The Basic Elements: Risk and Expected Return}

Portfolio theory divides all investments into two general types, those that are risky and those that are risk-free. If an investment has a number of possible outcomes, i.e., if the return it will produce may vary, then it is said to be "risky." On the other hand, if the outcome is certain and the return will not vary, the investment is "risk-free."19

18. The original sources of the theory are H. Mlaknowrtz, Porrfolio Selection: EFficient DIVErstrication of INvestMents (1959) and Tobin, Liquidity Preference as Behavior Toward Risk, $25 \mathrm{REv}$. EcoN. STUD. 65 (1958). Elementary Cxpositions of portfolio theory can be found in R. BREALEY, AN INTRODUCTION TO RISR AND RETURN Fros ComaloN Stocks 115-22 (1969), and W. Sharpe, Portrolio Theory and Cartral Mrankets 45-77 (1970).

19. Some economists distinguish between risk and uncertainty by postulnting a third category of investments whose risk and expected return cannot be specified. An investment is said to be risky when its outcome may vary and when the iniestor is able to make some estimate, either subjective or objective, of its risk and expected return. But if the investor cannot go that far and if he regards the future as unchartable, in the sense that he is unable to estimate risk or expected return, either subjectively or objectively, then he is sometimes said to face conditions of uncertainty, as distinguished from risl:. See W. Sharpe, supra note 18, at 25-26; and F. RENWICK, INTRODUCTION TO INVESTAIENTs AND FinANCE 148 (1971):

Uncertainty, compared with risk, formally means the lack of any knowledge, cren subjective judgment, concerning the probabilities associated with possible returns.

Other economists disagree with this definition of uncertainty, arguing that uncertainty exists whenever objective estimates alone are unobtainable. See D. E. FArRar, TIIE INiESTMENT DECISION UNDER UNCERTAINTY 2 (1967):

To qualify as a risk situation, then, an experiment must be repetitive in nature and must possess a frequency distribution from which observations an be drawn and about which inferences can be made by objective, statistical procedures. . . . Uncertainty; in contrast, is said to be present when the experiment in question cannot be carcfully replicated. ... Its frequency distribution therefore, cannot be objectively specified.

Portfolio theory offers no guide to investment choice when the investor is unable to make some estimate, either subjective or objective, of risk and expected returns, i.e., it fails to provide a rule for investment choice under conditions of uncertainty, as that term is defined by Sharpe and Rewick, supra. The failure of portfolio theory to deal vith investment choice under these conditions, however, is probsbly of little importance for the suitability rule. First, investments which present this situation are probably rare. It is usually possible for a security analyst to make some subjective estimate of security risk and return. Second, present securities law probably prohibits brokers from ever recommending investments that are "uncertain," according to the Sharpe-Renwidi definition. Under the SEC shingle theory, a broker is held to certain implied representations when he "hangs out his shingle," L. Loss, Securrries Reculation 482-69 (1951). 
Since any investment is made in anticipation of the returns it may produce, portfolio theory assumes that investment decisions can be made on the basis of two measures which characterize the set of possible returns. ${ }^{20}$ The first is risk, which measures the amount of variation among all the possible returns an investment may produce. ${ }^{21}$ The second is expected return, the weighted average of all the possible returns. Expected return itself consists of two components. The first or risk-free component equals the rate of return on risk-free investments, and compensates the investor for deferring the use of his funds until some later date. The second or risk component rewards the investor for accepting the possibility of variation in the return he will receive. Since investors are presumed to be risk-averse and to demand more compensation for assuming larger risks, the risk component must grow as the perceived variability of an investment increases.

These two measures, risk and expected return, can be combined into a single quantity, or index number, which measures the return per unit of risk. It is computed by subtracting the risk-free rate of return from the investment's expected rate of return, and then dividing by the degree of risk associated with the security. For example, if the risk-free rate of return is 5 per cent, a security that is expected to return 11 per cent and has a 4 per cent degree of risk, has an expected return per unit of risk of $11-5 \div 4$, or 1.5 .22

The "shingle theory" has been interpreted by the SEC and the courts as prohibiting a broker from recommending a security for purchase unless he has an adequate basis for evaluating it. See SEC v. Hanly, 415 F.2d 591, 592 (2d Cir. 1969). If a broker cannot make any estimate of the risk and expected return associated with a given security, then he clearly lacks an adequate basis for evaluating its prospects and so is prohibited by the "shingle theory" from ever recommending so-called uncertain investments. Thus, portfollo theory's assumption that the investor is always able to make some estimate of risk and expected return poses no serious obstacle to its usefulness in the area of securitics regulittion.

20. This assumption may be unrealistic. Two investments of like risk and expected return may still have different sets of possible returns, and some investors may carc about the difference. See J.C. Francis \& S.H. Archer, Portrolio ANalysis, 201.05 (1971); Alderfer \& Bierman, Choices With Risk: Beyond the Mean and Variance, $49 \mathrm{~J}$. Bus. 841 (1970); Linter, The Valuation of Risky Assets and The Selection of Risky Investments in Portfolios and Capital Budgets, 47 Rev. Econ. \& STAT. 13 (1965). See also pp. 1617.19 infra.

21. This assumes that risk is in fact the equivalent to the amount of variation among all possible returns that an investment may produce. Some economists might argue thit this assumption is unrealistic. But see note 56 infra. Statisticians call the measure of the amount of variation of all possible returns the "standard deviation of returns." "The mathematical formula for the standard deviation is explained in J.C. FruNCIs \& S.II. ARCHER, supra note 20, at 15-16.

For a discussion of alternative definitions of risk, see Bower \&: Wippern, Risk-Rcturn Measurement in Portfolio Selection and Performance Models: Progress Report, 4 J. FiN. \& Quant. ANaL. 417 (1969).

22. This example is derived from a similar example appearing in Lintner, $A$ Model of a Perfectly Functioning Securities Market, in ECONOMIC POLICY AND THE REGULATION OV Corporate Securtites 127, 152.53 (H. Manne ed, 1969). Where expected return is expressed in terms of percentage returns, then so is the degree of risk. This occurs because risk is assumed to be equivalent to the standard deviation of returns. See note 21 supra. 
2. Portfolio Theory and Adjusting for Risk: The Separation Theorem Portfolio theory distinguishes between two types of investment portfolios: risky and risk-free, the latter being composed of the investor's holdings of such risk-free investments as insured savings accounts and United States Savings Bonds. The total portfolio is the combination of the risky portfolio and the risk-free portfolio, and is by definition the investor's entire wealth..$^{23}$

Investors obviously differ with respect to the amount of risk they are willing to bear. ${ }^{24}$ It is often assumed that the investor's capacity and willingness to bear risk should be reflected in the degree of risk of the risky portfolio. ${ }^{25}$ According to this theory, a low-risk, blue chip portfolio would be suitable for the timid widow, while a portfolio of high-risk stock in unproven uranium mines might be suitable for the aggressive young speculator. Portfolio theory flatly rejects this view, which focuses solely on the nature of the investor's risky assets, and looks instead to the overall degree of risk incurred by the investor's total portfolio of both risky and risk-free assets. ${ }^{20}$ The choice of risky investments, according to portfolio theory, should be wholly independent of the investor's risk-bearing capacity. The investor should attempt to identify that portfolio of risky assets which he believes will produce the highest return per unit of risk. ${ }^{27}$ This portfolio can be denoted the "best" or optimal portfolio of risky assets obtainable. ${ }^{88}$ He then adjusts for risk by varying the proportion of his total wealth placed in this best risky portfolio. ${ }^{29}$ If the risk incurred by the best risky portfolio is greater than the investor desires to bear on his total portfolio, he

23. In applying these definitions, it should be remembered that the risky portfolio includes the investor's non-security, as well as security, investments. In addition, the investor's earning potential should be counted as either a risk-free or risky asset, as the case may be. For example, a tenured professor who expects to earn $\$ 25,000$ a year for life is in roughly the same position as a retired (and permanently disabled) investor of the same age with a life tenancy in United States Savings Bonds which produce $\$ 25,000$ a jear. On the other hand, the earnings potential of a commission salesman may be more akin to a high-risk security.

24. This statement is technically incomplete. Portfolio theory assumes that investors demand to be paid for assuming risks, and that return as vell as risk must be considered whenever an investor decides to accept or reject any given investment. Under this view, investors do not differ with respect to risk alone, but rather with respect to the amount of return they demand for assuming any given degree of risk. For practical reasons, however, this article contends that the law should focus primarily on the degree of risk alone, in isolation from return. See pp. 1623-25 infra.

25. R. BREALEY, supra note 18, at 115 .

26. Economic theory, which focuses on portfolio risk, is contrasted with various legal methods of regulating risk in Note, The Regulation of Rishy Investments, 83 HArv. L. REv. 603 (1970). The Note, however, does not discuss the NASD or SEC suilability rules.

27. Lintner, supra note 22 , at 152-53.

28. W. SHARPE, supra note 18 , at 69.

29. R. BREALEY, supra note 18 , at 122 . 
simply invests part of his funds in risk-free assets. ${ }^{30}$ The overall risk incurred by all his invested funds (the portfolio of risky assets plus the portfolio of risk-free assets) will decrease in direct proportion to the amount of wealth placed in risk-free assets. ${ }^{31}$ If the investor wishes to incur risk at a higher level than that of the best portfolio, he can borrow, investing the proceeds in the best portfolio up to a level that satisfies his preferences. ${ }^{32}$ The overall risk incurred by his total portfolio will increase in direct proportion to the amount of the risky portfolio that is leveraged..$^{33}$ The proposition that investors should adjust for risk in this way is known as the "separation theorem." 34

The portfolio with the largest return per unit of risk is best because, in conjunction with risk-free assets or borrowing, it can produce a higher return than any other portfolio at any given level of risk. Assume, for example, that United States Savings Bonds, with no risk, return 5 per cent; that portfolio $A$, with a risk of 2 per cent, returns 7 per cent; and that portfolio $B$, with a risk of 4 per cent, returns 11 per cent. If an investor were willing to incur a risk of 2 per cent on his invested funds, he could achieve that risk level by placing all his funds in portfolio $A$, earning a return of 7 per cent. Alternatively, he could invest 50 per cent of his funds in portfolio $B$ and 50 per cent in United States Savings Bonds. Then the overall risk of his invested funds would still be only 2 per cent, but the rate of return would be 8 per cent. Notice that the return per unit of risk in portfolio $B$ $(11-5 \div 4=1.5)$ exceeds that in portfolio $A(7-5 \div 2=1.0)^{30}$ This same analysis would apply regardless of the level of risk preferred

\footnotetext{
30. Id. at 118 .

31. Id.

32. Id. at 119 .
}

33. An investment is "leveraged" when it is purchased with borrowed funds. The overall risk of a total portfolio will increase in direct proportion to the amount of the investment that is leveraged. Thus, a highly leveraged investment in a risky portfollo with a low degree of risk will incur a higher overall degree of risk than if the portfolio were purchased without borrowing.

34. The separation theorem does not necessarily imply that the same portfolio of risky securities is best for all investors. One man's best portfolio may differ from another's at any given point in time because of tax considerations, transaction costs, and non-sccurity risky assets. See pp. 1629-30 infra. Moreover, even for one given investor, the composition of the best risky portfolio may vary over time as economic conditions change and the securities market reaches new equilibria. However, for a discussion of the selection of the best risky portfolio when the securities market is an "efficient market," see p. 1620 infra.

There is one additional consideration which may cause the best portfolio to vary from investor to investor. Suppose that the rate of interest on risk-free assets is not the same as the rate at which individuals can borrow (which is obviously the case in the real world). Then the best portfolio will vary, depending on whether the investor adjusts for rlsk by purchasing risk-free assets or by borrowing and investing the procecds in the best risky portfolio. See J. C. FRANCIS \& S. H. ARCHER, supra note 20, at 126-27.

35. Bower \& Wippern, supra note 21, at 418.

36. See note 22 supra. 
by the investor. Portfolio $B$, which has a larger return per unit of risk, will always be superior to portfolio $A$ when combined with risk-free assets or borrowing. Portfolio theory thus does more than demonstrate an alternative method of adjusting for risk. It concludes that it is more efficient to adjust for risk by varying the proportion of total wealth invested in the best portfolio of risky assets than by changing the composition of one's risky portfolio. ${ }^{37}$ Thus, a risky portfolio of high-risk uranium stocks may be risk suitable for the timid widow, provided that most of her wealth is in United States Savings Bonds. Likewise, a highly leveraged portfolio of blue-chip stocks may carry a risk that is appropriate for an aggressive young speculator. ${ }^{38}$

\section{The Theory of Diversification}

As a general rule, the portfolio of risky assets which is best will consist of a combination of securities, rather than some single security. This is explained by the theory of diversification. Although the expected return of a portfolio is the weighted average of the returns of individual securities within the portfolio, portfolio risk is usually not the weighted average of the individual risks. If all securities in a portfolio are expected to react in exactly the same way to all future events, the risk of the portfolio will equal a weighted average of the individual risks. But to the extent that the individual securities react differently to the same future events, aggregate portfolio risk is reduced..$^{30}$ Prudent

37. R. BREALEY, supra note 18 , at 122 .

38. The best portfolio of risky securities is that which, in conjunction with the investor's non-security risky assets, produces the highest retum per unit of risk for the investor's entire portfolio of risky assets. Therefore, the best portfolio of risky sccurities may vary from investor to investor due to variations in holdings of non-sccurity risky assets. See p. 1630 infra. The valuation of property requircs estimating the future income flows which the property can be expected to produce, and then discounting these flows to the present by some appropriate factor that takes account of the degree of risk involved. See generally J. BONBRIGHT, THE VALUATION OF Property (1937). In practice, the valuation of an investor's non-security risky assets may prove very difficult where there is no ascertainable market value for the asset in question. Perhaps the best example of this is the problem of the valuation of an investor's earning potential. Such valuation first requires estimating the salary that the investor can be expected to earn in future jears. Second, it is necessary to select some rate of interest at which to discount these future earning prospects. Because of the numerous factors which often affect any given individual's employment situation, estimation of either variable is likely to prove difficult.

39. The principle of diversification can be illustrated by the following example. Suppose investors can purchase the stock of Warco, which manufactures weapons, or Peaceco, which builds low-income housing. The performance of Warco depends on the size of the defense budget, as indicated in the following table:

\begin{tabular}{lcc}
\hline \multicolumn{1}{c}{ Event } & $\begin{array}{c}\text { Probability of } \\
\text { Occurrence }\end{array}$ & Return-Warco \\
\hline Large Defense Budget & $1 / 3$ & $12 \%$ \\
Medium Defense Budget & $1 / 3$ & $8 \%$ \\
Small Defense Budget & $1 / 3$ & $1 \%$ \\
\hline
\end{tabular}


investors, therefore, tend to increase the number of their holdings, or diversify, in pursuit of this reduction of aggregate portfolio risk. Of course securities often react in exactly the same ways to the same future events, and to the extent that this is unavoidable, investors will be unable to reduce risk through diversification.

Because increasing the number of holdings usually does reduce the aggregate portfolio risk, investors seeking to maximize the amount of expected return obtainable at any given degree of risk will diversify. Suppose, for example, that security $A$ and security $B$ each return 10 per cent with a medium degree of risk, while security $C$ returns 7 per cent with a low degree of risk. At some particular level of risk, in this example a low degree of risk, the investor has the opportunity of earning a return of 7 per cent by investing solely in security $C$. But if securities $A$ and $B$ react in sufficiently different ways, a portfolio composed of both may carry as low a degree of risk as security $C$. The investor would then be able to maintain a low risk position, by holding a diversified portfolio of $A$ and $B$, while obtaining an expected return of 10 per cent instead of 7 per cent. By lowering aggregate portfolio risk below the weighted average of individual risks in this manner, diversification holds out to the investor the possibility of reaping larger returns for any particular level of risk incurred on the

The performance of Peaceco depends on government expenditures for non-defense purposes, which are always inversely propertional to expenditures for defense, c.g., a large defense budget means a small non-defense budget and low earnings for Peaceco. The performance of Peaceco can be related directly to the size of the defense budget, in indicated by the following table:

\begin{tabular}{lcc}
\hline \multicolumn{1}{c}{ Event } & Probability of & Return.Peaceco \\
\hline Oarge Defense Budget & Occurrence & $4 \%$ \\
Medium Defense Budget & $1 / 8$ & $8 \%$ \\
Small Defense Budget & $1 / 8$ & $12 \%$ \\
\hline
\end{tabular}

If an investor decides on a portfolio divided equally between Warco and Peaceco, then he can expect the following results:

\begin{tabular}{lcccc}
\hline \multicolumn{1}{c}{ Event } & $\begin{array}{c}\text { Probability of } \\
\text { Occurrence }\end{array}$ & $\begin{array}{c}\text { Return } \\
\text { Warco }\end{array}$ & $\begin{array}{c}\text { Return } \\
\text { Peaceco }\end{array}$ & $\begin{array}{c}\text { Return } \\
\text { Averagc }\end{array}$ \\
\hline Large Defense Budget & $1 / 3$ & $12 \%$ & $4 \%$ & $8 \%$ \\
Medium Defense Budget & $1 / 3$ & $8 \%$ & $8 \%$ & $8 \%$ \\
Small Defense Budget & $1 / 3$ & $4 \%$ & $12 \%$ & $8 \%$ \\
\hline
\end{tabular}

Since Warco and Peaceco always react in exactly opposite ways to the same event, a portfolio composed equally of both securities will not vary. In the real world, however, this is rarely the case. To the extent that sccurities react in exactly the same way to future events, diversification will be unable to eliminate portfolio risk. The theory of diversification is discussed in the works cited in note 18 supra. 
risky portfolio. ${ }^{40}$ Diversification, then, becomes an important consideration in selecting that risky portfolio which is optimal, i.e. which promises the highest return per unit of risk.

The extent to which diversification works to reduce portfolio risk is a function of three factors: a) the number of different holdings; b) the proportions in which different securities are held; and c) the extent to which the securities held react in dissimilar ways to the same future events. ${ }^{41}$

A considerable amount of inquiry has been directed to the question of how many securities are needed to maximize the risk reduction afforded by diversification. Various studies, both theoretical and empirical, suggest that the marginal benefits of diversification decrease rapidly, and that beyond a certain point increasing the number of holdings has a neglible effect on portfolio risk.:2 Furthermore, brokerage fees per dollar invested, for the average investor, tend to increase with the number of holdings, due to the costs of engaging in odd-lot transactions. ${ }^{43}$ At some point, therefore, the decreasing marginal returns to further diversification are likely to be outweighed by the increasing transaction costs of achieving such diversification. Every major

40. Alternatively, diversification can be viewed as enabling the investor to minimize the degree of risk associated with any given level of expected return. See note 39 supra.

41. R. BREALEY, supra note 18, at 126.

42. Fisher \& Lorie, Some Studies of Variability of Returns of Investments in Common Stocks, 43 J. Bus. 99, 109-34 (1970), studied the effect of increasing the number of holdings in a portfolio for all stocks listed on the New York Stock Exchange over a forty year period. They concluded that roughly 40 per cent of maximum achievable diversification is obtained by holding two stocks; 80 per cent by holding eight stocks; 90 per cent by holding sixteen stocks; and 95 per cent by holding thirty-two stocks.

Evans \& Archer, Diversification and the Reduction of Dispersion: An Empirical Analysis, $23 \mathrm{~J}$. Fn. 761, 767 (1968), measured the diversification in random portfolios containing from three to forty securities chosen from 470 of the securities listed in the Standard and Poor's Index for the year 1958 . They concluded that "the results . . raise doubts concerning the economic justification of increasing portfolio sizes bejond io or so securities." R. BREALEY, supra note 18, at 124-28, constructed a model of a securitics markict in which he assumed that all stocks had the same individual risk, that any pair of stodis had the same co-variance, and that 30 per cent of the outlook for each stod ras contingent on the market as a whole. He then generated portfolios consisting of from 2 to 2,000 securities and found that: 1) once a portfolio consisted of six stocks, there was less than a 1 per cent decrease in portfolio risk for each security added; 2) that above ten securities, there was a decrease in risk of less than $1 / 2$ of 1 per cent for each security added; and 3) above twenty securities, there was a decrease in risk of less that $1 / 10$ of 1 per cent for each security added. Brealey also cites an unpublished Ph.D. dissertation, Gaumnitz, Investment Diversification Under Uncertainty: An Examination of the Number of Securities in 3 Diversified Portfolio, 1967 (Stanford University). Gaumnitz took a sample of 140 different stocks and found that increasing the number of holdings beyond eighteen did not produce any significant gain in diversification.

43. The commission charges set by the Nery York and American Stock Exchanges for "odd lot" transactions are a decreasing function of the dollar amount involved; therefore, transaction costs per dollar invested will tend to rise as the investor increases the number of securities held and divides his wealth into smaller and smaller lots. STANDASD \& POOn, STOCK GUIDE 225 (1971). 
study of this issue has indicated that, for the small or average investor, the best portfolio of risky assets is likely to contain, at the very most, twenty different securities. ${ }^{44}$

\section{The Theory of Efficient Markets}

Portfolio theory indicates that the rational investor should maximize the amount of return per unit of risk on the risky portfolio. There are two general ways in which this may be accomplished. First, as noted above, the investor can diversify his holdings. Second, he can attempt to purchase securities which are undervalued by the market.4v An undervalued security is one which produces a higher return at a given level of risk than other individual securities bearing the same degree of risk. The addition of undervalued securities to a portfolio will thus raise portfolio return for any particular level of risk, thereby raising the level of return per unit of risk on the entire risky portfolio. This gain in portfolio performance is independent of diversification, and occurs regardless of whether the addition of the undervalued security contributes to efficient diversification.

The difference between diversification and the purchase of undervalued securities can be illustrated by the following example. Suppose an investor holds security $C$ which is expected to return 7 per cent at a low degree of risk. Suppose that there also exist securities $A$ and $B$ producing 10 per cent at a medium degree of risk, and security $D$ which yields 10 per cent at a low degree of risk. If $A$ and $B$ in combination bear a low degree of risk because of diversification, an investor can increase his return per unit of risk by diversifying between them. On the other hand, he can obtain security $D$ which is undervalued relative to security $C$. This acquisition would also raise the amount of return per unit of risk, whether or not security $D$ lowers aggregate portfolio risk below the weighted average of the individual security risks. ${ }^{40}$

There is, at present, a growing body of opinion among economists and financial theorists that investors are rarely, if ever, able to identify

44. See note 42 supra.

45. Undervaluation and overvaluation are opposite sides of the same coin. If security $A$ is undervalued relative to security $B$, then security $B$ is overvalued relative to sccurity A. See C. Grancer \& O. Morganstern, The Predictability of Stock Martiet Prices 9.12 (1970).

46. If an investor in fact had these two opportunities simultaneously, information as to the co-variances of the securities would be required to enable him to decide whether to purchase $A$ and $B, D$, or perhaps all three, thereby both diversifying and purchasing an undervalued security. 
and acquire undervalued securities. ${ }^{47}$ This opinion follows from a proposition known as the theory of efficient markets, which views stock prices as fully reflecting all available information about securities at any particular moment. ${ }^{48}$ When new information becomes available which alters the risk or return prospects for a particular security, the theory of efficient markets argues that no investor is able to use the information to generate systematic profits. ${ }^{20}$ One explanation offered for this result is that there are so many analysts studying the market that "competition will cause the full effects of new information of intrinsic values to be reflected instantaneously in stock prices."

If the theory of efficient markets accurately describes reality and there are no undervalued securities, or if those securities are impossible to identify, the theory of optimal investment choice is profoundly affected. An investor seeking to maximize the return per unit of risk on his risky portfolio would have only one course of action-efficient diversification. Once efficiently diversified, a search for undervalued securities would be futile. ${ }^{51}$

47. If investors are unable to acquire undervalued securities, then they are necesarily unable to acquire any overvalued securities. See note 45 supra.

48. Theoretical and empirical literature in the field is comprehensively reviewed in a recent article by Fama, Efficient Capilal Markets: $A$ Revicw of Theory and Empirical Work, $25 \mathrm{~J}$. FIN. 383 (1970). The literature on the efficient market theory is both extensive and highly technical. Perhaps the best introduction for the lajman is another article by Fama, Random Walks in Stock Market Prices, 21 Fin. ANal. J. 55 (1965). There is also a short, non-technical explanation of the theory in Sharpe, Mutual Fund Performance, 39 J. Bus. 119, 120-21 (1966). Early work in this field, including both the articles heretofore cited, referred to the proposition in question as the "Theory of the Random Walk:" However, it is now generally recognized that the random walk theory is a specialized case of the more general efficient markets model. See Fam3, Efficient Capital Mfarticts, supra at 356-57.

49. To argue that it is impossible to make systematic profits is not to say that success or failure in the stock market is impossible. But the efficient markets theory does maintain that, aside from efforts to obtain more efficient diversification or to minimize transaction costs, success or failure is necessarily the result of tolally random factors. This view: is reminiscent of the philosophy expressed by Winston Niles Rumfoord, "founder of the Church of God the Utterly Indifferent," in K. VONNECUT, ThE SIRENS OF TrraN 253 (1959): "I was the victim of a series of accidents, as are we all."

50. Fama, Random Walks in Stock Afarket Prices, supro note 48 , at 50.

51. There is some disagreement about the impliations of the efficient markets theory for investment strategy. Two alternative strategies, each based on the proposition that undervalued securities cannot be identified, have been developed. Under the first, or buyand-hold strategy, investors simply diversify efficiently at the level of risk they are willing to assume and then hold. The investor is advised that switching is not profitable because it is futile to attempt to increase portfolio efficiency by switching to undernlued securities.

Recent work has challenged the buy-and-hold strategy on the ground that a portfolio is unlikely to remain efficiently diversified through time, and that periodic switching may be necessary to maintain the optimal amount of diversification. As a consequence, Evans has argued that the best course is to follow a Fixed Investment Proportion Araintenance (FIPM) strategy under which the investor periodically re-allocatcs his funds so that the same proportion of dollars is maintained in each of the individual securities as was originally allocated. For example, if the portfolio initially consisted of equal dollar amounts of three securities, funds would be periodically allocated to maintain this proportion. Such re-allocation would be necessary to maintain the original proportions whenever 


\section{An impressive body of evidence has been compiled in support of} the theory of efficient markets, ${ }^{52}$ and little statistical evidence contradicts it. The adequacy of the evidence in support of the theory, however, is a subject of disagreement, ${ }^{53}$ and for this reason some doubts

there were different relative changes in the prices of the sccuritics held. The FIPM strategy, it is argued, is superior to the buy-and-hold strategy because cfficient diversifica. tion is a function of the proportions in which securities are held. Under the buy-and-hold strategy, a portfolio which was initially diversified efficiently may become less well. diversified over time with changes in the original proportions of the securitics. Sec Evans, An Analysis of Portfolio Maintenance Strategies, 25 J. FrN. 561 (1970); Evans, The Random Walk Hypothesis, Portfolio Analysis and the Buy and Hold Criterion, III J. FiN. \& QuANT. ANaL. 327 (1968).

The FIPM strategy is superior to buy-and-hold only if the transaction costs incurred in maintaining original securities proportions are more than offset by the increase in cfficient diversification. In the first article cited above, Evans conducted a comparatve test of both strategies for 23,870 portfolios generated at random from the Standard and Poor's Index from 1958-1967. His results indicate that the FIPM strategy will equal or surpass the buy. and-hold for those investors who either pay capital gains tax at a rate of no more then 15 per cent or hold at least $\$ 2500$ worth of securities. In making his computations, Evans assumed that dividends paid would not be consumed and would be reinvested. 'Therefore, in computing results for the buy-and-hold strategy, dividends paid were used to purcliase additional shares of the stock on which they had been paid. In computing results for the FIPM strategy, the dividends paid were used to maintain original securitics proportions. Evans' results overstate the case for the FIPM strategy because of this assumption with respect to the use of dividends. Many investors consume at least part of their dividends, and these investors would be forced to incur considerably higher transactions costs in pursuit of the FIPM strategy than those investors who are able to reinvest their dividends.

The FIPM strategy assumes that 1) the original set of portfolio proportions was optimal and remains optimal and 2) co-variances of securities remain unchanged through time If these assumptions are unjustified, then some other investment strategy may be superior to both buy-and-hold and FIPM.

52. Although this article cannot present all the evidence offered in support of the thcory of efficient markets, one of the most important studies deserves mention. The Wharton Study examined the performance of mutual funds for the period from 1951 to 1962 and found that

the average performance of mutual funds was not appreciably better than what would

have been achieved by a completely unmanaged portfolio with the same distribution

between common stocks and other assets. About half the funds performed better and

half worse than such an unmanaged portfolio. This analysis also revealed the absence

of any significant relationship between performance and turnover [i.e., switching].

These results imply that fund shareholders did not benefit from high turnover.

The mutual funds studied engaged in substantial switching while the randomly chosen portfolios were simply held for the period under consideration. Since mutual funds are reputedly able to buy the best investment advice, they should be able to identify and acquire undervalued securities if it is possible. However, mutual funds appear to liave performed no better than random. See generally WhaRTon School. OF FinsNce AND CoMMERCE, A STUdy of MUTUAL Funds (1962). The summary of this study is taken from I. Friend, M. Blume \& J. Crockett, Mutual Funds and Otiler Institutional Investons $(1970)$. Other studies of mutual funds have produced similar results indicating that mutual fund managers are unable to identify and acquire undervalued sccuritics. See, c.g." Jensen, Risk, the Pricing of Capital Assets, and the Evaluation of Investment Porifolios, 42 J. Bus. 167 (1969); Jensen, The Performance of Mutual Funds in the Pcriorl 1915.61, 23 J. Fin. 389 (1968); Sharpe, Mutual Fund Performance, 39 J. Bus. 119 (1966).

53. After summarizing the empirical evidence offered in support of the efficient markets hypothesis, Fama concludes that

in short, the evidence in support of the efficient markets model is extensive and (somewhat uniquely in economics) contradictory evidence is sparse. Nevertheless, wc certainly do not want to leave the impression that all issues are closed.

Fama, Efficient Capital Markets, supra note 48, at 422.

The efficient markets theory is sometimes stated in three different forms depending on the extent to which market prices are believed to reflect available information. The wcak 
remain as to the theory's validity. Should the proposition that it is impossible to identify and acquire undervalued securities become adequately established,54 the theory of efficient markets will have a strong claim for integration into the legal suitability standard.

\section{B. Integration of Economic Theory Into the Legal Standard}

In the abstract world of economic models, the selection of the most suitable investment appears easy. The investor simply chooses the risky portfolio with the highest return per unit of risk and then divides his wealth between the best portfolio and risk-free assets in proportions that reflect his willingness to incur risk. Yet there are minor theoretical and major practical objections to an attempt simply to transform the theoretical model into a legal rule. These objections do not, however, prevent portfolio theory from making a major contribution to a substantive rule of suitability.

\section{Restrictive Assumptions of Portfolio Theory}

Portfolio theory is premised on a number of restrictive assumptions which at first appear to conflict with reality and thus to threaten the feasibility of building a legal rule on the theory." Such objections, however, prove to be of little practical importance.

form postulates that it is impossible to identify and acquire undervalued securities on the basis of information concerning past price performance. The semi-strong form states that this is also true for all publicly available information. Finally, the strong form states that no investors have access to non-public information which they can use to identify and acquire undervalued securities. The empirical evidence supports both the weak and semi-strong forms of the efficient markets theory, while the studies have produced evidence inconsistent with the strong form. See generally Fama, supra note 48 and note 54 infra.

54. Economists have noted two minor deviations from the efficient markets model. First, specialists on the major security exchanges sometimes have monopolistic access to information on unexecuted orders which may be used to generate trading profits. See Niederhoffer \& Osborne, Market Mlaking and Reversal on the Stock Exchange, $61 \mathrm{~J}$. AM. STAT. Ass'N 897 (1966). Second, there is evidence that corporate insiders may have monopolistic access to information about their own frrms which indicates that its stod: is misvalued by the market. See M. Scholes, A Test of the Competitive Hypothesis: The Market for New Issues and Secondary Offerings, 1969 (unpublished Ph.D. thesis, Graduate School of Business, University of Chicago). However, these deviations are unimportant for the overwhelming proportion of the investment community. As Fama has written: At the moment ... corporate insiders and specialists are the only two groups whose monopolistic access to information has been documented. There is no evidence that deviation from ... the efficient markets model permeste any further down the investment community.

Fama. Efficient Capital Markets, supra note 48, at 415. See note 53 supra.

55. See note $\mathbf{5 3}$ supra.

56. A recent treatise states that portfolio theory is based on the following assumptions: 1. All investors visualize assets as probability distributions of expected returns over some holding period.

2. Investors' risk estimates are proportional to the variability of expected returns.

3. Investors are willing to base their decisions solely in terms of expected return and risk.... 
The first questionable assumption is that all investment decisions can be made on the basis of two measures: risk and expected returns. Two investments may share the same risk and expected return while having different patterns of possible returns. Statisticians have developed two variables, skewness and kurtosis, to describe differences in the patterns of returns. ${ }^{67}$ To the extent that investors care about the skewness or kurtosis of alternative investment opportunities, por-

4. For any given level of risk, investors prefer higher returns to lower rcturns . . . Or, conversely, for any given level of rate of return, investors prefer less risk over more risk.

J.C. Francis \& S.H. ARcher, supra note 20, at 7.

To the above, I would add the following assumption:

5. Assets which are entirely risk-free do exist.

The theory of portfolio selection discussed at TAN $19-55$ supra, can be deduced entirely from these five axioms. The text of this article discusses only assumptions 3 and 5 , since it is only these assumptions which may, in the author's opinion, involve a significant departure from "reality." Assumption 1 is equivalent to assuming that investors can always make some estimate, either subjective or objective, of the risk and expected return of an investment. The consequences for portfolio theory when this is not the case are minimal, and are discussed in note 19 supra.

Assumption 2 is equivalent to defining "risk" as the amount of variability in the possible outcomes of an investment. This was assumed to be the proper definition of risk on TAN 21 supra. However, this definition can be attacked on the ground that investors are concerned primarily with the risk of loss alone, rather than with variation over the whole range of possible outcomes. For example, Francis and Archer note,

[t]he risk definition given in assumption two does not conform to risk measures coin.

piled by some popular financial services. The published quality ratings scem im.

plicitly to define risk to be the probability of default.

J. C. FRANCIS \& S. H. ARChER, supra, at 8. However, if the risk of loss or probability of default is highly correlated with the variability of return, then assumption 2 would appear to be valid. There will be a high correlation between the variability of all possible returns and the risk of loss, if the distributions of security returns are nearly symmctric. And, "most studies published thus far indicate [that] the distribution of [sccurity] returns are symmetric." J. C. FRANCIS \& S. H. ARCHER, supra, at 16. Therefore, assumption 2 is probably justified. The studies which indicate that the distributions of security returns are nearly symmetric are cited in note 59 infra.

The first part of assumption 4 is equivalent to saying that people will generally prefer more money, all other things being equal. If this is not an accurate description of rcality, then it is difficult to know what is. The second part of assumption 4 is a little more controversial. There may be individuals who are inveterate gamblers and will prefer higher risks to lower risks, even if the returns are the same, because of the pleasure thcy obtatin from risk-taking per se. Inveterate gamblers, however, usually go to the race track or Las Vegas to satisfy their needs. The typical investor in securities who needs the pro. tection of the suitability rule is undoubtedly risk-averse.

There are some economists who reject entircly the notion that it is meaningful to spcak of the axioms of a theory as being "realistic" or "unrealistic." They argue that the only possible test of a theory is "predictability," i.e., the accuracy of its predictions. According to the "predictivist thesis," one theory is rejected in favor of a second theory whenever the second theory produces more accurate predictions than the first. See firicdman, The Methodology of Positive Economics, in M. FrIEDMan, Essays IN Positive Economics (1966). However, it is not possible to use this standard insofar as portfolio theory is concerned, because there is really no other competing theory with which to comparc its predictions. When the predictivist thesis cannot be used, the decision to reject or accept at theory may require a consideration of the "reality" of its axioms. See S. Toulann, Fone. SIGHT AND UNDERSTANDING: AN INQUiRY INTO THE AIMS OF SCIENCE (1961).

57. The mathematical formulas for skewness and kurtosis are set out brielly in J.G. FRANCIS \& S.H. ARCHER, supra note 20, at 202-03. 
folio theory fails to take account of investor preferences. ${ }^{\text {t3 }}$ As a practical matter, however, this theoretical imperfection is effectively mooted, for neither investors nor brokers are normally able to incorporate preferences as to skewness or kurtosis into their investment decisions. 53

The second questionable assumption of portfolio theory is that riskfree assets exist. It may be argued, however, that even those investments typically regarded as risk-free, such as United States Savings Bonds and insured savings accounts, are in fact subject to inflation risk. This article adopts the contrary view, that the inflation risk of savings accounts and government bonds is insignificant, and develops a set of suitability rules based on the existence of risk-free assets. Investment choice is thus guided by the separation theorem, with a suitable risk level obtained through adjustments in the proportion of money invested in

58. See note 20 supra.

59. On a theoretical level, the introduction of skewness and kurtosis only makes portfolio theory as we have discussed it incomplete. They could be incorporated into the model by denoting as rational an investment choice which rejects a porfolio with the highest return per unit of risk in favor of a risky portfolio with a lower return per unit of risl: where the skew and kurtosis characteristic of the second portfolio are sufficiently advantageous to outweigh the sacrifice in yield.

A strong argument for ignoring both variables is that, as a practical matter, it is usually impossible to identify or predict the skew or kurtosis characteristics of particular investments. In order to calculate them, the investor must be able to specify in some detail the set of possible returns the investment may be expected to produce. This set of possible returns is known as a probability of frequency distribution, and consists of each possible return the investment might produce and the probability of occurrence associated with each possible return. In practice, investors are rarely, if ever, able to specify a complete probability distribution for each investment they are considering. Usually the investor simply makes some estimate of the degree of risk and the amount of return which he expects the security to produce. Although he can guess at the amount of variation in the returns (the risk), he usually has no basis for specifying in detail the probability distribution. The fact that investors estimate risk and expected return in this way is not inconsistent with the assumption of portfolio theory that investors are able to visualize assets as probability distributions of expected returns. See note 56 supra; J. C. FrANCIS \& S. H. ARCHER, supra note 20, at 8:

[V]isualizing probability distributions need not be explicit. "Mlost likely" estimates are undoubtedly prepared either explicitly or implicitly from a subjective probability distribution.

Moreover, even if investors were able to estimate skewness and kurtosis, they would probably ignore both variables. First, a large number of statistical studies show that, at least historically, distributions of security returns are approximately symmetrical, which is to say, all have zero skewness. See Osborne, Brownian Motion in the Stock Mfarket, III Operations Research 145 (1959); Blume, Portfolio Theory: A Step Tourard Ils Practical Application, 43 J. Bus. 163 (1970); Fama, Behavior of Stock Marliet Prices, 38 J. Bus. 34 (1965); Kendall, Analysis of Economic Time Series, I: Prices, J. Rovar STAт. Soc. Il (1953). But for evidence of deviations from symmetry, see Miandelbrot, The Variation of Certain Speculative Prices, 34 J. Bus. 392 (1963).

As for kurtosis, there is some question as to what it means and exactly what it measures, even when it can be estimated. In J. C. FrANcIs \& S. H. ARCHER, supra note 20, at 212, the authors state, "[I]t is not entirely clear what fourth moments [kurtosis] measure or how" they affect investor utility." Thus, most investors would probably ignore the fourth moments even if they were known. See also Kaplansky, $A$ Common Error Concerning Kurtosis, 40 AM. STAT. Ass'N J. 259 (1945). 
the risk-free portfolio. If a broker or investor is of the view that riskfree assets do not exist, an appropriate adjustment to the rules developed in this article can be made. ${ }^{60}$ In either case, the basic contribution of portfolio theory, which is to focus attention on the entire portfolio rather than on any single security, is unimpaired.

\section{Practical Problems}

The most serious objection to implementing a suitability rule premised on portfolio theory is the difficulty of identifying the optimal portfolio of risky assets, a difficulty which would be compounded if this determination were to be attempted after the fact by a court. If the theory of efficient markets is accepted, this problem is greatly reduced, since under that theory all efficiently diversified portfolios of a particular degree of risk offer the same expected return. ${ }^{01}$ Recom. mendations would then be examined in only two relatively simple ways: to discover whether more efficient diversification was achieved, and whether the resultant risk was appropriate for the customer.

If we do not accept the efficient markets theory, there is no objective way of determining in advance which risky portfolio will be the uniquely defined optimum. ${ }^{62}$ Nor can the best portfolio be pinpointed

60. Such an adjustment is made in the footnotes accompanying the rules devcloped in Part II. See notes 73 and 79 infra. Some brokers and investors may belicve that risk-free assets do not exist, viewing the inflation risk incurred by United States Savings Bonds and insured savings accounts as too significant to be ignored. If there are no risk-frec assets, all possible investments fall into the risky portfolio and the scparation thcorcm! becomes an empty shell. Portfolio theory in that case would still focus on an in: vestor's entire portfolio in considering a particular investment. A suitable level of risk would be achieved not by varying the proportions invested in risky and risk-frec portfolios, however, but by adjusting the risky portfolio itself. The investor would cloosc that risky portfolio with the highest return at the desired level of risk. Sce J. C. FRANcis \&. S. H. ARCHER, supra note 20, at 130-31.

61. See Sharpe, Mutual Fund Performance, 39 J. Bus. 119, at 121:

In a perfect capital market, any properly diversified portfolio will be efficient;

the... [investor] must select from among alternative diversified portfolios the onc

with the appropriate degree of risk.

62. The best portfolio is selected by evaluating the risk and return to be expected fron all possible combinations of securitics. There are two basic methods of making this evaluation. If it is believed that a security's risk and expected return in the future will not differ from what they have been in the past, then its future performance is sald to be susceptible of "objective" derivation on the basis of empirical evidence of past bchavior. On the other hand, if it is believed that the future may differ from the past, then the future performance is said to be "subjectively" specified, since it cannot be bascd on objective historical results.

But even the so-called objective evaluation is subjective. Its use of objective standards is founded on the subjective belief that the future will not materially differ from the past. Therefore, both methods involve subjective elements, and there is no way of making a truly objective determination of the best portfolio. See J. C. FrANcis \& S. H. ARcilcr, supra note 20 , at 35 on the estimation of risk and expected return:

The security analyst could obtain these inputs from historical data. Or, he can sub. jectively estimate these inputs. If the historical data are accurate and conditions in the future are expected to resemble those in the period in which the data were derlved, the historical data may be the best estimate of the future. But if the analyst is 
on the basis of subjective business judgment and informed opinion. Financial analysts can often concur as to the general degree of risk that can reasonably be expected from any particular portfolio. On the basis of such a consensus established by expert testimony, an adjudicatory body could determine whether a portfolio was of the general degree of risk appropriate for the customer. But analysts often disagree about a portfolio's exact placement within a general class. For example, most analysts would agree that both American Telephone \& Telegraph and General Motors stocks carry a relatively low degree of risk, but they would often disagree as to which of the two, within that general class, can be expected to be less risky. The situation is similar with respect to determination of expected returns.

Selection of the optimal portfolio, however, requires considerably more than simple placement of a portfolio within a general class. Optimization refers to a single best portfolio to be selected from a broad range of possibilities on the basis of its return per unit of risk. Because analysts will be unable to reach a consensus on the ranking of all alternative portfolios, they will necessarily disagree widely about which portfolio is, at a moment in time, optimal. A workable suitability rule thus could not impose on a broker or dealer the obligation of recommending the optimal risky portfolio.

\section{Investor Preferences and Legal Suitability}

Portfolio theory seeks to equate total portfolio risk with the level of risk that the investor is willing to bear. It focuses, in other words, on the risk preferences, or the willingness to bear risk, of the individual investor. Mundheim suggests that the legal suitability standard should go further, and consider, in addition, whether the risk is one which the investor has the capacity or ability to bear, notwithstanding customer preferences and desires:

The principal aim of these procedures should be a definition of each customer's risk threshold. The risk threshold concept is broader than the concept of investment objective. Investment objective expresses what the customer wishes to achieve from his investment in relation to his willingness to bear risk. Risk threshold refers to the customer's willingness and ability to bear risk. ${ }^{23}$

Ability or capacity to bear risk, or risk threshold, are terms which

"expert" or the market is changing, subjective estimates may be preforable to historical data.

See also Sharpe, supra note 18, at 25.

63. Mundheim, supra note 7 , at 474 (emphasis added). 
refer to that amount of risk which a prudent investor, in the customer's circumstances, would be willing to incur. A widow with a moderate amount of capital, for example, might be anxious to speculate and to incur high risks. But such speculation would be beyond her ability or capacity to bear risk if a prudent investor in her situation would not adopt that strategy.

It is not proposed that the law absolutely prohibit a broker from selling a security which would raise portfolio risk above the risk threshold. If an investor persisted in requesting such a security, a capacity. to-bear-risk standard would permit the broker to make the sale, provided that he first warn the investor that the purchase was dangerous and imprudent. . $^{64}$

This notion of risk threshold, requiring brokers to warn customers about purchases which would result in imprudent levels of risk, would increase the flow of information available to the investor and protect against the hazards of high-pressure security salesmanship. Investment in securities can be fantastically complicated and technical for the lay investor, and brokers typically exert great influence over customers' in. vestment choices. Without a compulsory warning, a customer may be influenced by his broker to express a preference for a risk which he does not fully understand and which he is not really willing to undertake.

By incorporating the notion of risk threshold, suitability would be defined with respect to both willingness and capacity of the customer to bear risk.

64. Some might consider a warning inadequate and believe that only an absolute pro. hibition would adequately protect investors. An absolute prohibition, however, inight be attacked on the ground that it interferes with consumer sovereignty by substituting the risk preferences of the prudent or reasonable man for those of the investor in question. To the extent that an absolute prohibition, if adopted, did interfere with the ability of sovereign consumers to make imprudent or speculative investments, it would not be unlike other laws which prohibit individuals from placing their resources in great jeopardy in the hope of making a large gain, such as laws against gambling. It would bo stup. portable, if at all, on similar policy grounds, for example, to avoid the destitution of individuals who would otherwise be self-supporting. It could be argued, however, that insofar as securities are concerned, a rule which attempts to substitute the prudent man's desires for those of the investor in question may actually, in the long run, do more to further individual desires than would a mere warning. Suppose that a compulsory warning is insufficient to protect customers from undue broker influence, and that most investors will, if allowed to decide freely, make prudent choices. $A$ rule which focuses on the prudent man's desires, then, may only prohibit brokers from infuencing their customers to choose a risk that does not, in fact, reflect their true preferences.

If these suppositions are correct, the absolute prohibition, far from bcing a usurpation of consumer sovereignty, seems instead a way of fortifying it against the possible distorting influence of high-pressure securities salesmanship. If a compulsory warning is found to protect investors inadequately, the SEC should seriously consider an absolute prohibition. 


\section{Can Risk Be Regulated In Isolation From Return?}

This article has thus far considered the decision to accept or reject a given level of risk as if it could be made simply by comparing the risk in question with the customer's risk threshold. A recent Note, however, criticized this general approach:

[R]eturn as well as risk must be evaluated when deciding if an investment is imprudent. For a prudent private investor, the expected return may more than offset the corresponding marginal increment in risk resulting from [a purchase].5

[I]nvestors ... benefit from investments that increase the return to a portfolio just as they are harmed by investments that increase its risks. [Current regulation of risk] ignores this trade-off between risk and return .... a larger expected return may more than off-set the marginal risk a security adds to a portfolio. ${ }^{\circ 0}$

[R]isk cannot be regulated without making a judgement about the level of return that will justify a certain level of risk. ${ }^{67}$

According to this critique, an investor is characterized not by his attitude toward risk alone, but by the amount of return he demands for assuming any given level of risk. When an investor is said to prefer "low risks," therefore, this can only mean that he is unwilling to acquire most high-risk and medium-risk portfolios available in the market, because he considers the expected returns they offer insufficient to compensate him for the higher risk they carry. A high-risk or medium-risk portfolio may be acceptable to a so-called low-risk investor, however, if its expected return is sufficiently large to compensate him for the higher risk involved. The critique therefore suggests that regulation should compare both the risk and expected return of the total portfolio recommended

65. Note, The Regulation of Risky Investments, 83 HARv. L. Rev. 603, 608 (1970).

66. Id. at 618 .

67. Id. at 621. Contrary to the view expressed above, however, the rejection of certain portfolios on the basis of risk alone is theoretically proper if it is believed that some risk levels are never acceptable, no matter how much expected return they offer. For cxample, suppose an investor has capital of $\$ 100,000$ and is offered the chance to play the following game. The investor is required to bet (i.e., to invest) his entire wealth of $\$ 100,000$. There are two possible outcomes, each with a probability of 50 per cent. Under outcome one, the investor loses everything. Under outcome two, the investor wins and is entitled to receive any sum he wishes, no matter how large. The question is, how large a pay-off will induce the investor to play the game? There are some investors who will not mind the risk of losing everything because of the possibility of enormous gain. But there are other individuals who prefer prudence to the risk of losing everything, no matter how large the possible gain. The regulation of risk in isolation from return is tantamount to assuming that a so-called low-risk prudent investor is unwilling to incur medium or high risks, no matter how much return they promise, because the risk of loss is so great. It may not be unreasonable to assume that prudent men-whoever they may be-are especially concerned about the risk of loss and therefore vill reject any portfolio whose 
with the investor's individual risk-return preferences; or, at least, that a broker-dealer should be allowed to defend a high-risk recommendation to a so-called low-risk customer on the ground that the returns were large enough to justify the high risk.

Such a critique is certainly theoretically superior to the view that preferences toward risk are established without regard to expected return. Portfolio theory assumes that investors demand larger expected returns for assuming higher risks, and it follows from this assumption that the level of risk an investor is willing to bear will, in part, be a function of the reward offered for risk-taking. It is possible, however, to demonstrate that regulation with respect to risk alone is theoretically consistent with the view that risk-taking is a function of expected return, under a special set of conditions: if the efficient markets theory holds, all efficiently diversified portfolios at any given level of risk can be expected to produce the same amount of return. ${ }^{0 s}$ Therefore, an investor will either accept or reject all efficiently diversified portfolios at any given level of risk, and it is possible to characterize investor preferences in terms of the level of risk alone.

As noted above, it is not currently possible to say whether the efficient markets theory accurately describes the behavior of all securities prices for all investors. The evidence amassed in its support, however, does indicate that in the overwhelming majority of cases it is impossible to identify and acquire undervalued securities or undervalued portfolios. At any given point in time, then, the great majority of efficiently diversified portfolios can be expected to offer the same return at any given level of risk. And, at least with respect to those portfolios, it is possible to characterize investor preferences with respect to risk alone.

The regulation of risk in isolation from return remains theoretically improper with respect to those (doubful) instances when a broker may be able to identify and acquire undervalued portfolios which produce an unusually high return at their level of risk. It may be argued that in these instances, a broker should be allowed to defend a high-risk recommendation to a so-called low-risk customer on the ground that the portfolio recommended is so undervalued and produces such unusually high returns that it is consistent with the customer's willingness and capacity to bear risk. But let us examine this proposed defense more closely. Would it be fair to allow the defense when a recommendation is

risk of loss exceeds some minimum threshold, regardless of the possible returns, Ste D. FarRaR, The INVEstMient Decision UNDER UNCERTAINTY 9.10 (1967).

68. See the discussion of the efficient markets theory at pp. 1614-17 supra. 
alleged to have exceeded the customer's willingness to bear risk? Suppose a broker recommends a high-risk portfolio to a customer who expresses a preference for a low-risk recommendation. Should the broker be allowed to defend himself on the ground that the customer, in spite of himself, would have been willing to assume the higher risk because of the unusually high returns involved? Such a defense could be evaluated only by determining what the customer would have said, had the broker at the time of the recommendation asked him if he would be willing to accept a high-risk recommendation which promised unusually high returns. But how could an adjudicatory body determine this after the fact? Clearly, in this instance, the broker should actually ask the customer. It is the obligation of a broker, under the present suitability rule, to inquire about his customer's preferences before making a recommendation. He is forbidden from making a recommendation by guessing about his customer's desires. For this reason our hypothetical broker should not be allowed to defend a recommendation that is inconsistent with the customer's stated preferences on the ground that it is consistent with unstated, "real" preferences.

Is the proposed defense acceptable when a recommendation is alleged to have exceeded the customer's capacity to bear risk? Suppose for example that a broker recommends a high-risk portfolio to a customer of limited financial means. Should he then be allowed to defend the recommendation on the ground that even a prudent man in those circumstances would be willing to accept a high-risk portfolio, provided the returns were unusually high? It seems clear that the defense would be persuasive only where the broker is clearly able to identify and acquire a significantly undervalued portfolio-a situation which is not common. However, until doubts about the validity of the efficient markets theory are resolved, the suitability rule should recognize this possibility by allowing a broker to defend an allegedly risk-unsuitable recommendation by presenting clear and convincing evidence that: 1) the portfolio recommended was significantly undervalued and produced an unusually high return for its level of risk, and 2) the return was sufficiently high to justify acceptance by a prudent man of what would ordinarily be an unsuitably high risk.

\section{A Proposed Set of Suitability Rules}

Based on the foregoing analysis, portfolio theory and the legal suitability requirement should be integrated to produce the following rules. 
1. Brokers should recommend a security only if there is a reasonable basis for believing that its purchase will result in a risk which the customer is willing and able to bear. ${ }^{69}$ In order to make this judgment, the broker should compare the risk of the total portfolio which would result, if the purchase is made, with the customer's risk threshold. ${ }^{70}$ In no case should risk suitability be judged with respect only to the individual security recommended, apart from its effect on the customer's entire portfolio of both risky and risk-free assets.

2. Brokers should, in good faith, recommend that risky portfolio which they believe will produce the highest return per unit of risk, net of transaction costs. Adjustment of the resulting risk to suitable levels should be accomplished by varying the proportions of the customer's total wealth between risky and risk-free portfolios. ${ }^{71}$

3. Whenever a broker recommends that a customer acquire a portfolio consisting of more than twenty securities, that recommendation will be deemed unsuitable unless the broker can show clear and con* vincing evidence for believing that the increased benefits of further diversification exceed the larger transaction costs incurred. This rule shall not apply when the investor's holdings are sufficiently large that transaction costs per dollar invested do not increase with the number of holdings.

4. When a broker recommends the purchase of a security which does not improve the efficiency of diversification, and the recommendntion is not motivated by the investor's desire to hold his portfolio at a different level of risk, the recommendation is unsuitable unless there are reasonable grounds for believing that it will increase portfolio return, net of transaction costs.

5. Should the theory of efficient markets become adequately estab. lished, the following rule should replace Rule 4: When a broker recommends the purchase of a security which does not improve the efficiency of diversification, and the recommendation is not motivated

69. A broker should be allowed to justify a recommendation which exceds the customer's capacity to bear risk, by presenting the defense discussed pp. 1623.25 supra.

70. See pp. 1621-22 supra. Risk threshold includes the customer's willingness and ca. pacity to bear risk, where the latter is defined as the risk that a prudent or rcasonable min in the customer's circumstances would be willing to assume. This rule would not be th absolute prohibition against a broker recommending a purchase that excecled the in. vestor's capacity to bear risk. If an investor persisted in requesting such a recommendation, the rule would not prohibit the broker from making it, provided he first warncd the investor that the assumption of the risk was dangerous and unreasonable according to what a prudent man would do.

71. For a discussion of the applicability of this rule in the non-risk-free assets case, see note 79 infra. 
by the investor's desire to hold his portfolio at a different level of risk, then i) any recommendation that the investor switch his investments is per se unsuitable; and ii) any recommendation that the investor increase the number of his holdings is unsuitable, unless the total amount invested is sufficiently large that increasing the number of holdings does not increase transaction costs per dollar invested.

\section{A. Risk Suitability: Rule 1}

This rule incorporates a central insight of portfolio theory: that risk suitability should be judged with respect to the effect of a particular investment on the investor's total portfolio, rather than solely in terms of the particular investment's risk characteristics. A broker under Rule 1 would be required to make three determinations: first, he would determine the customer's capacity and willingness to bear risk; second, he would estimate the effect of the security's purchase on the risk level of the customer's entire portfolio of both risky and risk-free assets; ${ }^{72}$ third, he would compare the resulting degree of risk with the customer's risk threshold, and make appropriate adjustments.73

Although the SEC has failed to announce explicit criteria for judging risk suitability, its decisions and pronouncements have shown a practical awareness of the procedures outlined under Rule 1. The SEC has recognized that the suitability of any purchase should be evaluated by obtaining information concerning the customer's total financial picture, including his investments in both risky and risk-free assets. ${ }^{74}$

72. It should be noted that the purchase of a high-risk sccurity will not necessarily increase the overall risk of a portfolio, provided that the high-risk security and the portfolio react in sufficiently different wajs to the same future events. See pp. 1611-19 and note 39 supra.

73. When risk-free assets are available, the broker should adopt the following course of action if the degree of risk associated with the resulting total portfolio is inconsistent with the customer's risk threshold. If the resulting total portfolio vould be too risky for the customer, then the broker should recommend the security only if he simultaneously advises a decrease in the proportion of total wealth placed in the risky portfolio. If the resulting total portfolio rould carry too low a risk, then the broker should recommend the security only if he, at the same time, advises an increase in the proportion of wealth placed in the risky portfolio, through borrowing if necessary.

But if risk-free assets are not available, it is impossible to adjust for risk by varjing the proportion of assets placed in the risky portfolio, and the broker-dealer should change his recommendation to a different security or group of securities in order to bring the total portfolio risk to a level consistent with the customer's risk threshold.

74. In Gerald M. Greenberg, 40 S.E.C. 133, 137-38 (1960), the SEC noted that the broker had recommended the purchase of a security "without any knowledge of or attempt to obtain information concerning the customer's other security holdings, his financial situation, and his needs so as to be in a position to judge the suitability of recommendations." In SEC Release No. 34-7984 (October 25, 1966), the SEC stated that brokers should make inquiries concerning a customer's "savings and life insurance, and his security holdings and other assets." 
Moreover, the SEC decisions appear to compare the customer's risk threshold with the degree of risk associated with the total portfolio. ${ }^{76}$ Despite this general similarity of approach between portfolio theory and SEC decisions, however, the SEC has itself recognized that further definition of risk suitability would prove beneficial..$^{70}$

One ambiguity is whether the suitability rule as presently enforced by the SEC actually focuses on the customer's entire portfolio. ${ }^{77}$ Because of this uncertainty, brokers may hesitate to recommend an appropriate combination of the best risky portfolio and risk-free assets or borrowing, for fear that their recommendations may be scrutinized in terms of the risk suitability of the risky portfolio alone, or even in terms of the risk suitability of the particular security. If, for example, the best risky portfolio carries a high degree of risk, brokers may fear to recom. mend it, in combination with risk-free assets, to a low-risk investor. Brokers may similarly hesitate to recommend a risky portfolio containing both high-risk and low-risk securities for fear that risk suitability may be judged with respect to the individual high-risk security recommended, in isolation from the effect of this security on the total portfolio.

To the extent this ambiguity exists regarding the meaning of risk suitability, the suitability rule may have induced brokers to avoid recommendation of efficient investments. Rule 1 would clarify the current ambiguity.

\section{B. Economic Suitability: Rules 2 through 5}

Risk suitability as defined above is but one of the implications of

75. In Philips and Co., 37 S.E.C. 66 (1956), the SEC found a recommendation tustuitable where a customer, "in limited financial circumstances," placed all his wealth, includinf: borrowed funds, in a speculative security. In Richard N. Cea, SEG Release No. 34.8662 (August 6, 1969), the offending broker persuaded a widow in her late fiftics, who carned about fifty dollars per week take home pay, to sell her listed stocks and place all her wealth in a highly speculative security.

76. In SEC REport of Special Study of Securities Market 329 (1963), the SEC stated:

Greater emphasis should be given by the commission and the self-regulatory bodies

to the concept of "suitability" of particular customers. The NASD, which has taken

leadership in this respect by adopting a general suitability rule, should provide

further definition of content.

77. The SEC decisions have never articulated any explicit criteria for determining whether a recommendation involves a risk that is suitable for the customer in question. There is simply a listing of the relevant facts and then a statement to the effect that the recommendation was unsuitable. Because the facts recited by the SEC in the cases cited in note 75 supra have included information concerning all of the customer's assets and liabili. ties, the SEC appears to be comparing the customer's risk threshold with the risk assoclated with the total portfolio as a result of the security recommended. However, becaluse there is no explanation of what it is doing, the decisions might also be interpreted as simply coin. paring the customer's risk threshold with the risk of the particular security recommended, alone and in isolation from the rest of the customer's holdings. 
portfolio theory. While the theory argues that the customer's risk threshold should correspond to the risk incurred on his total portfolio, it does not suggest that all portfolios carrying that level of risk are equally desirable. It assumes instead that the investor will always prefer the total portfolio with the highest expected return for the degree of risk that he is willing to assume. This assumption can be translated into several kinds of suitability requirements concerning the economic suitability of broker-dealer recommendations.

\section{Rule 2: The Search for an Optimal Portfolio}

No workable legal standard, as noted above, can impose on brokers the duty to identify successfully the optimal portfolio of risky assets for each customer. ${ }^{78}$ Rule 2 is articulated in the interest of formulating a general method of procedure for brokers along the lines suggested by economic theory. A broker will have complied with Rule 2 if he can evidence a good faith effort to recommend the best risky portfolio. Rule 2 states that he should, in good faith, recommend that risky portfolio which yields the highest return per unit of risk, net of transaction costs. Adjustment for risk suitability should then be accomplished by varying the proportions of wealth held in risky and risk-free portfolios. ${ }^{70}$

Brokers will obviously recommend different "best" portfolios to customers with different risk thresholds. The portfolios recommended to customers with identical risk thresholds may also differ, however. For one thing, brokers will differ as to the composition of a "best" portfolio, being unable to agree on a uniquely defined optimum. Other reasons for this difference emerge from portfolio theory itself. The composition of the portfolio with the highest return per unit of risk may differ from customer to customer as a function of at least three additional factors. First, investors are primarily concerned with the after-tax return per unit of risk. Tax-exempt securities, which produce too low a return to justify their inclusion in the best portfolios of lorv- and middle-income investors, may produce a high enough after-tax return to justify their inclusion in the best portfolios of high-income investors. ${ }^{80}$ Second, if transaction costs vary among investors, the same portfolio may produce a different net return for different investors. ${ }^{81}$

78. See pp. 1620-21 supra.

79. See pp. 1609-11 supra. If brokers believe that risk-free assets are not atailable, they should, in good faith, recommend those securities which will produce the highest return, net of transaction costs, for the entire portfolio at the degree of risk which rellects the customer's risk threshold. See notes 60,73 supra.

80. R. BREALEY, supra note 18 , at 121. See note 34 supra.

81. Id. For example, suppose that, without taking transaction costs into account, the 
Third, customers will vary in their holdings of non-security risky assets, such as real estate or interests in unincorporated ventures. The best portfolio of risky assets must be assessed in conjunction with these non-security assets.

\section{Rule 3: Diversification}

The studies of decreasing returns to diversification indicate that increasing the number of securities in a portfolio above twenty is unlikely to improve portfolio efficiency more than negligibly. ${ }^{82}$ At the same time, increasing the number of holdings will probably increase transaction costs per dollar invested..$^{83}$ Any recommendation that an investor increase his number of holdings beyond twenty should be highly suspect, therefore, under the suitability rule.

This does not mean that any risky portfolio containing twenty or more securities is efficiently diversified. The proportions in which different securities are held and the degree to which their outcomes are independent of each other also determine portfolio risk. A portfolio in which 81 per cent is invested in one stock and 1 per cent is invested in each of nineteen other stocks is not well-diversified. Nor is a portfolio consisting of twenty different airline stocks likely to be efficient in reducing overall risk, since the fortunes of all companies within any single industry are significantly interrelated. If the portfolio holdings are held in correct proportions and if they are as independent of one another as possible, however, increasing the number of holdings beyond twenty will bring a negligible benefit.

Whether an increase in holdings is suitable thus depends on the type of transaction in question. If the investor is placing funds in securities for the first time, then a portfolio of more than twenty

\footnotetext{
"best" portfolio is composed of five securities, while the second-best portfolio is composed of only three of those five securities. An investor with relatively limited funds may incur significantly higher brokerage fees per dollar invested in the best portfolio, as compared with the second-best portfolio, because of the high cost of odd-lot buying. Mrorcover, if the difference in brokerage fees outweighs the greater return per unit of risk produccd by the best portfolio over the second-best portfolio, then the latter would actually be best for the investor with limited funds, when transactions costs are taken into account. On the other hand, a large institutional investor will purchase securities on a sufficient scalc to make the question of transaction costs immaterial. See note 43 supra.

82. See note 42 supra. None of these studies, however, attempted to take transaction costs into account. Since the extra transaction costs are probably more than negligible, it is likely that decreasing returns to diversification will be outweighed by Increasing transaction costs at some level significantly below twenty holdings, perhaps as low as cighit or so. Thus, the number twenty which has been suggested for incorporation into the legal rule is almost surely too high. Further statistical studies, taking into account increasing transaction costs as well as decreasing returns, would probably enable a somewhat lower figure to be incorporated into the rule.

83. See note 43 supra.
} 
securities is unlikely to be the best, and its recommendation should be held suitable only if the investor's holdings are sufficiently large that his transaction costs per dollar invested do not increase. When a purchase involves the investment of additional funds or the switching of funds already invested, there may be special circumstances which would justify increasing the investor's holdings above twenty. If an investor's existing portfolio is badly diversified, for example, an increase in the number of holdings above twenty may improve the efficiency of diversification. An investor whose initial portfolio contains twenty airline stocks and who wishes to invest additional funds would be well advised to buy the securities of a company in a completely unrelated area, although this would increase the number of holdings above twenty. Or, if an investor's portfolio consists of 81 per cent of one stock and 1 per cent of nineteen others, it may be proper to advise him to switch the 81 per cent in the one stock to a number of different securities. ${ }^{8 t}$

Because such situations are imaginable, Rule 3 has been drafted to provide a strong presumption against the suitability of any recommendation that an investor acquire more than twenty holdings, while allowing the broker a defense based on clear and convincing evidence that his recommendation was suitable under the circumstances.

\section{Rule 4: Bad Bargains And Churning}

Portfolio theory assumes that investors demand to be compensated for assuming risk. This assumption, in conjunction with the obvious fact that investors prefer larger returns, can be translated into two short maxims of investor behavior:

a) If two portfolios have the same risk and different expected returns, then investors will always prefer the portfolio with the larger return; and

b) If one portfolio has both a higher risk and a lower return than a second portfolio, then investors will always prefer the second portfolio.

84. The existence of transaction costs suggests other exceptions to the general rule imposing a ceiling of twenty holdings. Assume an investor holds an efficiently diversified portfolio $A$ with twenty securities, and later discovers a portfolio $B$ which produces a higher return than $A$ at the same level of risk. Suppose further that the differential retum between $A$ and $B$ is less than the transaction costs of switching but greater than the increase in transaction costs that would result from increasing the number of holdings by investing any additional funds in portfolio $B$. In this circumstance, the investor should not switch from portfolio $A$ to portfolio $B$. But if he wishes to invest additional funds, he should place them in portfolio $B$, even though such a choice vould raise the number of holdings above twenty. However, this situation is so unlikely that it may be ignored for practical purposes when implementing Rule 3. 
These maxims can easily be combined into Rule 4: when a brokerdealer recommends a security that does not decrease over-all portfolio risk, the recommendation is suitable only if there are reasonable grounds for believing that it will increase portfolio return, net of transaction costs.

Rule 4 is concerned with recommendations that may be risk-suitable but of no economic advantage to the customer. A recommendation may violate Rule 4 in two different ways. First, if the return on the security recommended is less than the return on the existing portfolio, its acquisition will obviously fail to increase portfolio return. Second, even if the new security produces a higher return than the existing portfolio, transaction costs may be so great that not even the highest reasonable estimate of the security's expected addition to portfolio return would justify its purchase.

As to the second situation, Rule 4 dovetails with the SEC's application of the suitability rule to "churning" cases, where a broker engages in excessive trading in a customer's account in order to generate commissions for himself. ${ }^{85}$ Under current SEC law, a finding of unsuitability in cases of "churning" implies that no reasonable basis existed for believing that the securities purchased would produce an economic advantage sufficient to offset the broker's commission. ${ }^{80}$

\section{Rule 5: The Impact of The Theory of Efficient Markets}

The substance of Rule 4 can be given further significance when integrated with the theory of efficient markets. Rule 5 is proposed to replace Rule 4, if the theory of efficient markets becomes adequately established. Consider the situation where a small investor who is efficiently diversified and who has no desire to change the level of risk of his portfolio places additional funds in securities. If the investor decides to increase his number of holdings, transaction costs per dollar invested will probably increase. ${ }^{87}$ The acquisition will be suitable under Rule 4 only if the net return of the portfolio increases. Thus the new portfolio resulting from the increase in the number of holdings must produce a higher return than the existing efficiently diversified

85. See note 14 supra.

86. In Thomas Arthur Stewart, 20 S.E.C. 196, 201 (1945), the SEC stated:

In view of the selling load included in the purchase price, in-and-out trading in the subject shares could be profitable only . . . if a purchase were followed by a market appreciation of the portfolio or an increase in the fund's net current assets sufficient to exceed the selling load of 8 per cent to $91 / 2$ per cent.

87. See note 43 supra. 
portfolio. This can occur only if the new portfolio is undervalued by the market, relative to the existing portfolio.

In a second case, where an investor who holds an efficiently diversified portfolio is advised to switch his investments, transaction costs are similarly increased.88 This cost increase can be justified under Rule 4 only if the new portfolio yields more, net, at the same level of risk, i.e. if the new portfolio is undervalued by the market relative to the existing efficiently diversified portfolio.

The consequences which follow if the theory of efficient markets is accepted should be apparent, since the contribution of that theory is its judgment that it is impossible to identify and acquire undervalued securities.

Rule 5 therefore would prohibit broker-dealers from recommending either: i) an increase in the number of holdings through the investment of additional funds to an investor who is efficiently diversified, unless his holdings are sufficiently large that his transaction costs per dollar do not increases as his number of holdings increases; or ii) the switching of already invested funds to any investor who is efficiently diversified. The only valid exception to this prohibition would be the case where an investor has changed his investment objectives and wishes to hold his portfolio at a different level of risk. ${ }^{89}$

\section{Conclusion}

Under rules of the SEC and NASD, a broker-dealer in the securities market may recommend a security for purchase only when there is a reasonable basis for believing that its acquisition would be suitable for the customer in question. Neither the SEG, the NASD, nor the courts, however, have attempted to define "suitable" or to articulate definite criteria for judging the suitability of a particular investment for a given customer.

Over the past fifteen years, academic economists have produced a con-

88. Id.

89. The study of Scholes, supra note 54 , indicates that it may be possible to identify and acquire undervalued securities on the basis of inside information. Therefore, the efficient markets theory, in one form, maintains only that it is impossible to identify and acquire undervalued securities on the basis of publicly available information. Sec Fama, Efficient Capital Markets, supra note 48, at 383,414 . This may suggest that a suitability rule based on the efficient markets theory, such as Rule 5, should allow an cxception for recommendations based on inside information. In view of the prohibition against the use of inside information by SEC Rule $10 \mathrm{~b}-5$, however, it would hardly be appropriate for a suitability rule to make such an exception. 
siderable body of theoretical and empirical literature in a search for definite criteria for judging the advisability or "suitability" of any investment. Economic research has made five basic contributions to a theory of investment choice. First, it emphasizes that the investor should choose a total portfolio consistent with his willingness and capacity to bear risk, rather than focusing simply on the extent to which individual securities in isolation pose acceptable risks.

Second, it demonstrates that, when risk-free assets exist, the most efficient way to adjust for risk is by varying the proportion of total wealth placed in risky and risk-free assets. Third, it indicates that the investor should always choose that total portfolio which produces the highest return for the level of risk consistent with his risk threshold. Fourth, the theory of diversification demonstrates that the optimal portfolio will typically consist of a number of securities rather than any single best security, but that after a certain number, at most twenty, increasing the number of holdings in a portfolio produces only a negligible benefit. Fifth, the efficient markets theory postulates that investors are unable to identify and acquire undervalued securities.

The economic theory of portfolio selection is based on a number of assumptions which initially appear too unrealistic to justify its incorporation into a workable legal standard. But, on closer exami* nation, such objections prove unimportant, and for all practical purposes portfolio theory provides an accurate description of the market for securities.

The most serious limitation on the usefulness of portfolio theory for the suitability rule is that there is no way of determining, on the basis of either an objective test or subjective judgment, what is at any given point in time the best portfolio for a particular investor. Therefore, the legal suitability rule cannot command recommendation of a single optimal portfolio. Despite this limitation, it is possible to give the present suitability rule considerable definitional content, extending governmental protection of investors in the securities markets by integrating the insights of theoretical and empirical research with the legal standard.

One possible objection to interpreting legal suitability in the light of economic theory is that it will make brokers' services more expensive. Portfolio theory, after all, is concerned with the risk-return attributes of the investor's entire portfolio, which includes not only his security investments, but his home, savings account, job prospects, and other significant non-security assets and liabilities. This means that a broker, operating under the suitability rule advocated here, would have to obtain complete information about each customer and analyze the data 
before making a recommendation. This would doubtless entail some increase in the price of brokers' services.

In part the expense of obtaining information about each customer's financial background could be minimized. Most of the necessary data about an investor's existing portfolio could be obtained from a standard form requesting vital statistics about a customer's job, securities, nonsecurity assets, liabilities, and other pertinent information. ${ }^{00}$ There would remain, however, the task of analyzing data from the form, and this procedure might be costly.

Such costs, however large, must be weighed against the substantial benefits which an expanded suitability rule would provide to the average investor. Implementation of the risk and economic suitability rules proposed would afford the investing public two sorts of benefits. First, the risk suitability standard, both as now enforced by the SEC and NASD, and as proposed, would protect investors from the unknowing assumption of imprudent risks, and from high-pressure securities salesmanship. Second, the economic suitability rules would prevent brokers from making recommendations which increase transaction costs without, on balance, improving the investor's position.

The suitability rules described above would employ the findings of theoretical and empirical economics to proscribe practices harmful to the average investor which are permissible under current law, and would give meaning to the currently inchoate policy requiring "suitable" investment recommendations. For these reasons the rules proposed here deserve the serious consideration of SEC and NASD policy makers.

90. According to Mundheim, supra note 7, at $474 \mathrm{n.86}$, such a form is now in use. 


\section{The Yale Law Journal}

Volume 80, Number 8, July 1971

\section{David M. Schulte Editor-in-Chief}

\author{
STEPHEN R. MIUNZER \\ Executive Editor
}

THOMAS M. JORDE

JOHN B. KUHNS

JERRY L. StegeL

Article Editors
JEFFREY I. GLEREL

STEPHEN J. HADLEY

ANDREW D. HuRwitz

DAvid H. KAYE

ERIC R. NEISSER

Note ir Comment Editors
Dean D. Aulick

Daniel J. Beller

George A. BermanN

RICHARD A. BLOCK

Richard Blumenthal

Barbara A. Brown

Gregory L. Golvin

Mrchael M. Conway

Richard J. Danzig

Richard D. DIAMIOND

John J. DYstel

S. Allen EARLY, III

J. Michael Eisner

Reid L. Felduan

ROger W. Fonseca

Gary L. Fontana

BRUCE G. FreEdMaN

\author{
NANCY GERTNER \\ Susan A. Goldberg \\ Peter T. Grossi, Jr. \\ TIMOTHY S. HARDY \\ OloF K. HellÉN \\ JAMES R. HUNTWORK \\ STANLEY N. INGBER \\ Ballard Jamieson, JR. \\ KENNETH M. KaUfMan \\ MARC S. KOPLIK \\ DANIEL J. KORNSTEIN \\ HAROLD J. KWALTWASSER \\ JOSEPH M. MALKIN \\ HaRold A. McDougali, III \\ ELLIOTT MIEISEL \\ STEPHEN A. OXMAN \\ JAY E. POWELL \\ Robert C. POZEN
}

LAURENCE S, LUSTGARTEN

Comment is Revietus

Editor

HENRY M. FiELDS

Managing Editor

Business Secretaries M. Olive Butterfield, Pamela Willmott

\section{Student Contributors to This Issue}

Kenneth M. Kaufman, The All-Purpose Parts in the Queens Criminal Court: An Experiment in Trial Docket Administration

Michael M. Conway, Imprisonment for Debt: In the Military Traclition 